\title{
Part One
}

Narrated Tableaux 


\section{Arrival-A Postcommunist Émigré in the Prairies}

\section{Anke Pinkert}

This personal essay reflects on the specters of communism in a post-1989 world, and on the possibility of new beginnings.

Keywords: Post-1989 literature; social and protest movements; displacement and travel; memoir

It's a dreary November afternoon in $2019 .{ }^{1} \mathrm{I}^{\prime} \mathrm{m}$ sitting in my campus office, at the University of Illinois, working on a keynote lecture for a conference commemorating the thirtieth anniversary of the fall of the Berlin Wall. The task appears reasonable and easy. After all, I grew up in East Berlin, in the district of Treptow, a spitting distance away from the Berliner Mauer [Berlin Wall]. In the fall of 1989, I joined the hundreds of thousands of demonstrators who marched silently in Leipzig, eventually bringing about the end of the GDR (even if this had not been their initial intention). I know the history and literature of East Germany inside out, and the postcommunist cultural landscape of Eastern Europe as a field of academic study is more than familiar. Today, however, I am distracted. Shouts of students echo into my third-floor office. Protesters have gathered on the quad, and they are now approaching the Foreign Languages Building, whose architecture, incidentally, resembles the brutalist style that pervades East Berlin, as I recall it.

When I moved here, to this small college town in the

${ }^{1}$ I would like to thank Cecilia Novero and Jeff Castle for invaluable feedback on this essay. 
middle of cornfields, in the summer of 2000 , I learned from a campus record keeper that the Foreign Languages Building (FLB) had been built to house a computerized learning system called PLATO. He went on to inform me that the FLB's first stone had been laid on December 18, 1968. In August of the same year-two or three worlds apart-Soviet tanks had crushed the vision of "socialism with a human face," putting an end to the Prague Spring. I didn't mention that to the friendly archivist. Nor did I tell him that shortly before that uprising I had been born into the collective citizenship of the GDR, the German Democratic Republic, a country one will no longer find on any map.

The irony of history is impossible to ignore now, I think to myself as I stare into the blank screen of my laptop. Three decades of leave-taking - from the GDR, from socialist East Berlin, and from a divided Cold War Europe-have left me stranded here, in the American Midwest. And all I do and think about as a scholar is communism. Even if the concrete wall that formed the impassive backdrop of my childhood had long since disappeared. Many younger residents of my former neighbourhood-indeed, an entire generation or two-never even laid eyes on what vanished from there; they have only heard the ghostly stories of an Unrechtsstaat [illegitimate state] in history class. It is true: the Antifascist Protection Wall-a militarized zone, complete with watchtowers and armed guards-had shaped the austere landscape of those early years. But, unfathomably perhaps, I only realized that after 1989, once the military bulldozers 


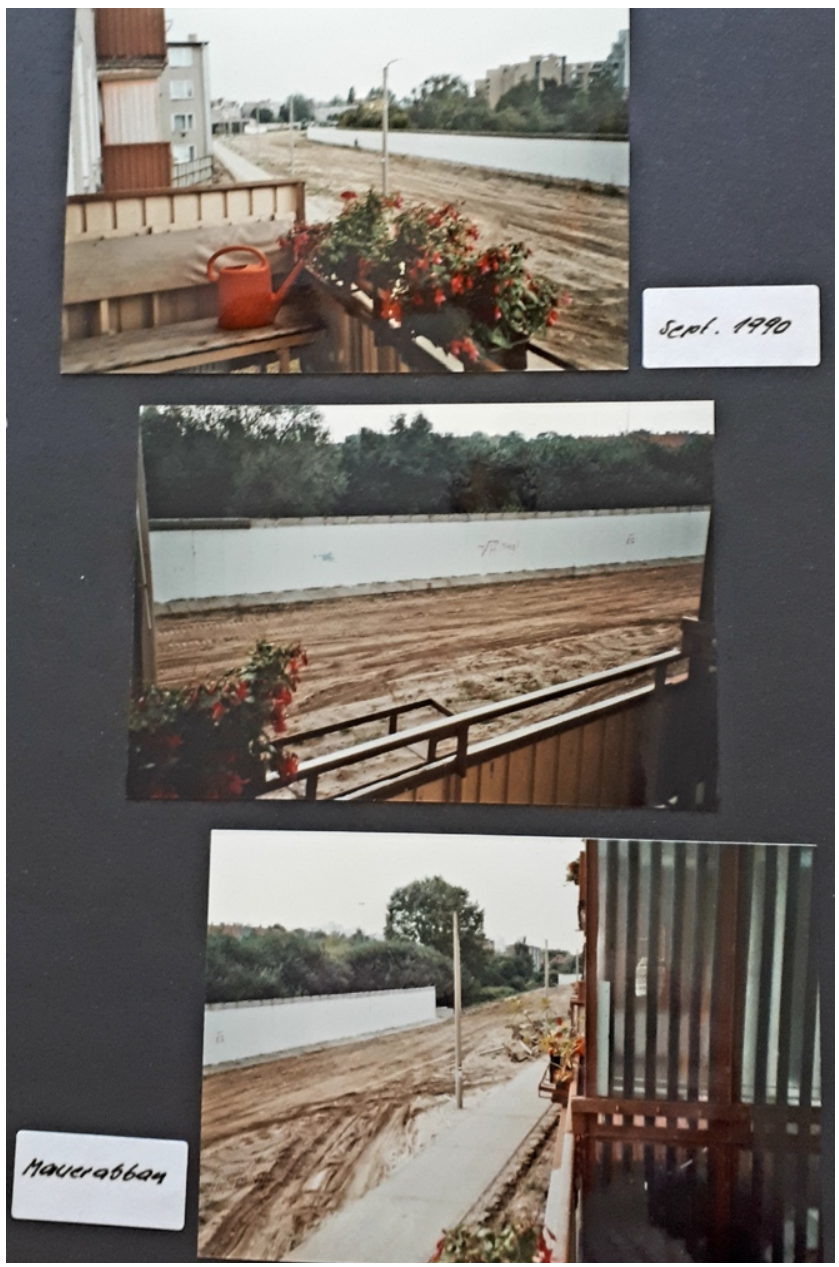

Dismantling of the Berlin Wall.

Berlin-Baumschulenweg, September 1990. (Photograph by Hanno Schmikale) $^{2}$

${ }^{2}$ For a secret snapshot of the view from the East into the West across the Wall before 1989, see a photograph by Gerd Rücker included in 
had reduced the structure to a pile of concrete panels and steel beams. For years to come the demolished border architecture left a terrain vague: everything was "eerily quiet like an abandoned November field." 3 Today, what stretches out in front of the 1960s tenements near the former border checkpoint Sonnenallee is an overgrown biotope, populated on most mornings by dog walkers, cyclists, and some scattered homeless people, clenching bottles of beer. Wall debris might still be in the underbrush. But only a halfhidden, city-commissioned sign reminds visitors lost in the struggling outskirts of the now booming, neoliberal capital city that this site is indeed on the Mauerpfad [Wall trail].

Inevitably, perhaps, I feel as if my life has been cut in half: there is the time before and the time after 1989. In between, a gap. When my students ask what it felt like when the Wall fell, I like to cite a fellow postcommunist traveler, a literary character who declares, "Am Morgen war es [mein früheres Leben] in ein Loch gefallen und verschwunden" [In the morning my former life fell into a hole and disappeared]. ${ }^{4}$ Nearly thirty years ago, in August of 1992, I left that earlier, other, orphaned part of my life behind, and blindly stepped onto an Airbus at Tempelhof Airport, bound for the United States. All I knew about the States was what I had seen in the photo-ethnographic study Amerikanische Bilder [American pictures], published in 1984 by the GDR press Volk und Welt. In this book, Dutch

\footnotetext{
Lydia Dollmann, Manfred Wichmann, eds., Fotografieren Verboten! Die Berliner Mauer von Osten gesehen. Mit Aufnahmen und Erinnerungen von Gerd Rücker (Berlin: Christoph Links Verlag, 2015), 104.

3 Jean Baudrillard, "Anorexic Ruins/1989," in Ruins, ed. Brian Dillon (Cambridge, MA: MIT Press, 2011), 67.

${ }^{4}$ Angela Krauss, Die Überfliegerin (Frankfurt: Suhrkamp, 1995), 62. My translation.
} 
journalist Jacob Holdt captures the devastation of impoverished, predominantly Black, inner-city neighborhoods in haunting black-and-white photographs. ${ }^{5}$ And yet, back then, most readers in the GDR, including me, had been oblivious to such stark racial and class inequities, focusing instead on the ongoing cultural appeal-the dream-of America.

Enrolling as a graduate student at the University of Chicago, on the city's segregated South Side, I quickly learned that reality had outlived propaganda. The two blue nylon suitcases I had landed with contained a few books, plates for food (why?), photographs, and other belongings I had scrambled together. My hasty departure had been somewhat out of necessity. After nearly all teachers at the Language Institute in Leipzig had been fired by the evaluators from West Germany, I began searching for alternatives to provide for myself and my young son. Mostly, however, I had an insatiable hunger to be far, far away from the proverbial 'walls in the head' that were quickly rising after Germany's reunification.

Post-1989 literature by East German authors often features characters who embark on expeditions and transnational travel once they deem themselves free-or freer, in any case. They race cross oceans, climb mountains, traverse the desert, propel themselves into the cosmos, or fly as supernatural, fantastical creatures around the globe through the air, testing out the limitlessness of radical new beginnings. In a lyrical 1998 narrative, East German writer Angela Krauss charts the celestial routes of an Überfliegerin [Over-Flyer] detached from ideological and historical

${ }^{5}$ Jacob Holdt, Amerikanische Bilder. Eine Reise durch das schwarze Amerika (Berlin: Volk und Welt, 1984). 
moorings. ${ }^{6}$ As she passes over Leipzig, Minneapolis, San Francisco, Novosibirsk, and Moscow, East turns to West and then to East again, only to leave the reader with a final scene in which the protagonist, along with Semjon, her partner in crime, shoots up like a rocket into unbound space, into the void. In a 2004 Frankfurt Lecture on Poetics, Krauss, who was born in 1950 in the GDR city of Chemnitz (later Karl-Marx-Stadt), renders this moment of liberation more uneasily. "Zerfällt meine Lebensgeschichte," she asked, "weil ihr der Rahmen genommen wurde, der ihr Form gab?" [Does my life story dissipate because the framework that shaped it has been taken away? ${ }^{7}$

Reading this question for the first time, I realized it put into words a feeling that had been lingering in me ever since I had embarked on my own transatlantic journey thirty years ago, leaving Germany for the West. Yet had I not also taken the opposite route? If Krauss's character became unbound, I had traveled five thousand miles only to return, unknowingly, over and again, to ingrained historical patterns, "frames," so to speak, that I had assimilated and that had "framed" me. ${ }^{8}$ Looking around at the books lining the shelves of my FLB office, I realized the

\footnotetext{
${ }^{6}$ Krauss, Überfliegerin. Fictional accounts of post-1989 transnational travel include

Helga Königsdorf, Gleich neben Afrika (Hamburg: Rowohlt, 1992); Christa Wolf, Stadt der Engel oder The Overcoat of Dr. Freud (Suhrkamp: Berlin, 2010); Eugen Ruge, In Zeiten des abnehmenden Lichts (Hamburg: Rowohlt, 2011). Among numerous films, see Petra Epperlein and Michael Tucker, Karl Marx City (New York: Bond/360 2016). See also Zafer Şenocak, Gefährliche Verwandtschaft (Fuchstal: Babel, 1994); Yoko Tawada, Das nackte Auge (Tübingen: Konkursbuch, 2010).

7 Angela Krauss, Die Gesamtliebe und die Einzelliebe: Frankfurter Poetikvorlesungen (Frankfurt: Suhrkamp, 2004), 78. My translation. ${ }^{8}$ Judith Butler, Frames of War: When Is Life Grievable? (New York: Verso, 2010).
} 
all too obvious, and the all too ironic: I had taken refuge once more at the epicenter of the Cold War. And I wasn't only thinking of the metal bookshelves surrounding me, mounted on bland cinderblock walls and bending under the weight of a twenty-year-old collection of Soviet-style pictures, Marxist political theory books, and tons of photographs, posters, and VHS tapes with faded, creased paper labels bearing titles such as "1968 (verboten) Die Russen Kommen" [1968 (banned) The Russians Are Coming]. Any visitor who takes a campus tour of the University of Illinois will be treated to an entertaining anecdote about the origins of the very building in which I sat. It is rumored that the interior layout of the FLB was intended to confuse Soviet spies and prevent them from stealing secrets off of PLATO, the supercomputer housed at its center. ${ }^{9}$ Further, the structure of the building was designed so that, in the case of a bombing, the shell would fall outward, protecting the data machine on the inside. As I contemplated this nuclear fantasy, in which the atomic age collided with the information era, I suddently felt rather exposed. Sitting, unsheltered, atop this secret artifact, I imagined surveying the rubble of the FLB bunker. Like 1945 , the year zero. Or 1989. ${ }^{10}$

\footnotetext{
${ }^{9}$ PLATO (Programmed Logic for Automatic Teaching Operations) was originally intended to assist higher-education institutions in dealing with increased enrollment following the 1944 GI Bill. It was the first computerized learning system, and its development was prompted by the advances of competitors. The USSR's 1957 launch of the Sputnik I artificial satellite spurred the United States government to invest more in science and engineering education. PLATO I-III had been funded by grants from a combined Army-Navy-Air Force funding pool. See Wikipedia, s.v. "PLATO (computer system)," last modified July 7, 2020, 20:41, https:// en.wikipedia.org/wiki/PLATO (computer system).

${ }^{10}$ Roberto Rossellini, Germany, Year Zero (Rome: Produzione Salvo D'Angelo and Tevere Film, 1948). Stark landscapes of exposure and
} 
And yet, on this late afternoon in the autumn of 2019, maybe due to the vulnerability I have just come to recognize, I feel safe; I can now look into the future with hope. More and more student activists are gathering on the quad to fight for a progressive agenda. Standing in front of the FLB, the massive faceless monolith, béton brut, the protesters cannot see into the tinted faculty offices, but as I look out, gazing through the maple tree lit up by dusk and swaying in front of the window, I sense an affinity. Laughing, shouting, a young woman in a black leather jacket and red beret hoists a fellow protester onto her shoulders so that together they are taller; standing out from the crowd, they wave a sign reading, "Bernie 2020. Not Me. Us" in the air. The activists' chants swell up and recede as they circle around the building: "Greater justice!" "Black lives matter!" "Health care for all!" and then "Equal pay!" and "Time is Up!" - voices in an emerging country-wide movement. I also hear rallying cries for local and national political candidates, a sign that preparations for the March 2020 primary elections are already ramping up.

Neither the protesters nor I are aware that only a few months later, amid the harrowing fallout of a global pandemic, yet another unarmed black man, George Floyd, will be killed by police and that the students' nascent demands for racial, social, and environmental justice will return and be reactivated, en masse, as hundreds of thousands of people take to the streets in the United States and around the globe. We cannot yet anticipate that COVID-19 will rage across the country, exposing the devastating health disparities that pervade American

\footnotetext{
devastation related to the fall of the Berlin Wall can be found, for instance, in Oskar Roehler, Die Unberührbare (Berlin: Distant Dreams, 2000).
} 
society, exacting a cruel toll on the poor, the disenfranchised, those abandoned by neoliberal economic policies-often Black, Indigenous and People of Colorand further enmeshing them in structures of institutionalized racism and economic injustice. It takes a virus, it turns out, to bring the ruins of the global capitalist system into full view, for all to see. ${ }^{11}$ With it, however, comes the possibility of forming alternative solidarities to resist, locally and internationally, the "looting of neoliberalism."12 In the midst of the pandemic, in this Midwestern town, I will later learn, a community-wide initiative will bring people of all income levels together to share garden tools and resources to grow food for themselves and their neighbours. In light of catastrophic disparities, the World Health Organization will issue a call for a collective, coordinated approach to combat the spread of the virus, one that engages the entire machinery of government- a call, in other words, for global cooperation. ${ }^{13}$ For now, in the late fall of 2019, watching a handful of students demonstrating on campus outside the FLB, my expectations are more measured. But still, I can't believe my luck. The "end of history," which was declared

${ }^{11}$ Wendy Brown, In the Ruins of Neoliberalism (New York: Columbia University Press, 2019), esp. 187.

${ }^{12}$ Mehrsa Baradaran, "The Neoliberal Looting of America," New York Times, July 2, 2020. For a return of the political after years in a postpolitical era, see Chantal Mouffe, For a Left Populism (New York: Verso, 2018).

${ }^{13}$ In reference to a declaration by the chief of the World Health Organization, Dr. Tedros Adhanom Ghebreyesus, on March 5, 2020, Slavoj Žižek called for a reinvented communism (or "disaster communism"), a collective approach of global solidarity and cooperation in which a global organization also regulates the economy and limits the sovereignty of nation-states when needed. See Pan-demic: Covid-19 Shakes the World (New York: Polity, 2020). 
so persuasively by Francis Fukuyama post-1989, ${ }^{14}$ and which has stretched through the perpetual now for the last decades, appears finally to be over.

In this moment, I've found the beginning of my keynote lecture. I recognize the young woman with the red beret: she is enrolled in my Post-Soviet Cinema class. Last Wednesday she had jumped up in the first row and asked, "So, are you a postcommunist émigré, or what?" I begin to hit the keys. An hour goes by. When I finally look up from the computer screen, I see that it has turned pitch black outside. All I can make out in the distance is the red warning signal for aircraft flickering atop the bell tower of the student-union. I get up and switch off the desk lamp. As I am leaving, my gaze catches on a piece of the Berlin Wall that sits on my industrial-style office desk. An otherwise unremarkable chunk of colorless concrete, the memento has gone unnoticed for the last two decades. Looking at it now, I can just barely make out the traces of my father's steady handwriting. The inscription penciled on nearly thirty years ago has almost become illegible: Rest der Berliner Mauer. Bln. Hänselstr. 1990.

${ }^{14}$ Francis Fukuyama, The End of History and the Last Man (New York: Free Press, 1992). 


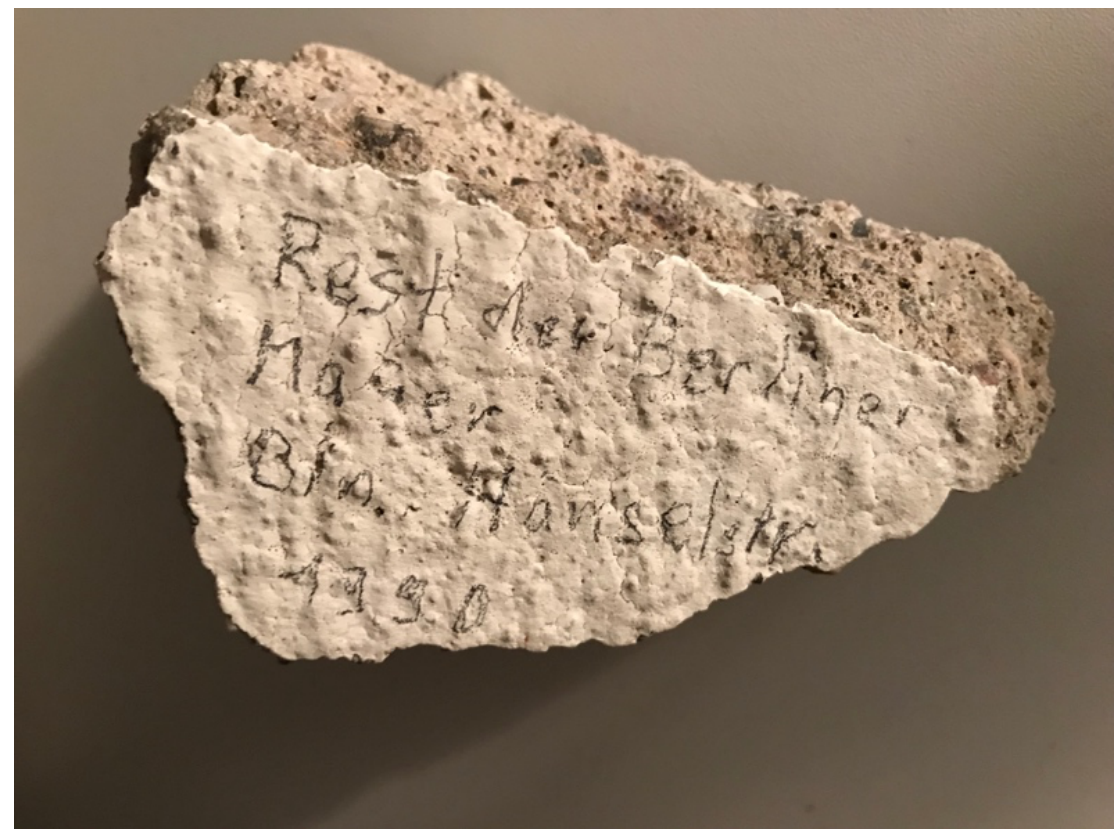

Remnant of the Berlin Wall. Bln. Hänselstr. 1990.

(Photograph by the author)

I suddenly grab the stone, fearing the cleaning crew. Imagine: they come through tonight and remove it without hesitation, mistaking the artifact for disposable rubble. I slip the piece into my coat pocket. When I step outside the Foreign Language Building onto the damp streets, I notice that the construction of the new African American Cultural Center, directly across the street, must have been recently completed. A university-branded sign is now visible in front of the façade, and students are congregating for an evening event. I' $\mathrm{m}$ still holding on to the prized possession as I pass by the group on my way to the parking garage; it 
feels like driftwood, or a fossil. ${ }^{15}$ But I, dare I say, feel renewed. Yes, this piece of Wall debris carries the weight of historical utopias, of their dreams of greater equality and social justice, as well as their false starts, detours, and failings. Indeed, as post-Soviet scholar Susan Buck-Morss reminds us, we need not lament the passing of the dreamworlds of modernity. Those dreamworlds were mired in their own blindspots; they were repressive, dismissive of non-European civilizations, and, at least implicitly, racist. $^{16}$

False starts, though, bear potentiality, I think to myself as I keep walking. There is indeed a blessedness in the dead thing in my palm. History is not closed down but rather propels itself from states of crisis into future movements. Living in this full state of liminality, I am convinced now that a new revolutionary horizon is opening up in this country. The radically democratic impulses of the nonviolent uprising in the GDR in 1989-90 may even come into play. Suddenly, I realize that while I may be a postcommunist émigré-or, for that matter, a traveler, a green card holder, or a legal alien in the US-I am also someone who has arrived. And, as history has taught me, each arrival affords a new vantage point. Collective action and the unrealized potential of the past still lie ahead.

\footnotetext{
${ }^{15}$ Eric Santner, Stranded Objects: Mourning, Memory, and Film in Postwar Germany (Ithaca, N.Y.: Cornell University Press, 1993).

${ }^{16}$ Susan Buck-Morss, Revolution Today (Chicago: Haymarket Books, 2019), 38.
} 


\section{Works Cited}

Baradaran, Mehrsa. "The Neoliberal Looting of America." New York Times, July 2, 2020.

Baudrillard, Jean. “Anorexic Ruins/1989." In Ruins, edited by Brian Dillon. Cambridge, MA: MIT Press, 2011.

Brown, Wendy. In the Ruins of Neoliberalism. New York: Columbia University Press, 2019.

Buck-Morss, Susan. Revolution Today. Chicago: Haymarket Books, 2019.

Butler, Judith. Frames of War: When Is Life Grievable? New York: Verso, 2010.

Dollmann, Lydia, and Manfred Wichmann, eds. Fotografieren Verboten! Die Berliner Mauer

von Osten gesehen. Mit Aufnahmen und Erinnerungen von Gerd Rücker. Berlin: Christoph Links Verlag, 2015.

Epperlein, Petra, and Michael Tucker. Karl-Marx-City. New York: Bond/360, 2016.

Fukuyama, Francis. The End of History and the Last Man. New York: Free Press, 1992.

Holdt, Jacob. Amerikanische Bilder. Eine Reise durch das schwarze Amerika. Berlin: Volk und Welt, 1984.

Königsdorf, Helga. Gleich neben Afrika. Hamburg: Rowohlt, 1992.

Krauss, Angela. Die Überfliegerin. Frankfurt: Suhrkamp, 1995.

Krauss, Angela. Die Gesamtliebe und die Einzelliebe: Frankfurter Poetikvorlesungen. Frankfurt: Suhrkamp, 2004. Mouffe, Chantal. For a Left Populism. New York: Verso, 2018.

Rossellini, Roberto. Germany Year Zero. Rome: Produzione Salvo D'Angelo and Tevere Film, 1948. 
Roehler, Oskar. Die Unberührbare. Berlin: Distant Dreams, 2000.

Ruge, Eugen. In Zeiten Des Abnehmenden Lichts. Hamburg: Rowohlt, 2011.

Santner, Eric. Mourning, Memory, and Film in Postwar Germany. Ithaca, N.Y.: Cornell University Press, 1993.

Şenocak, Zafer. Gefährliche Verwandtschaft. Fuchstal: Babel, 1994.

Tawada, Yoko. Das nackte Auge. Tübingen: Konkursbuch, 2010.

Wolf, Christa. Stadt der Engel oder The Overcoat of Dr. Freud. Suhrkamp: Berlin, 2010.

Žižek, Slavoj. Pan-dem-ic: Covid-19 Shakes the World. New York: Polity, 2020. 